\title{
DISTRIBUTION AND ABUNDANCE OF ARTEMIA SALINA IN THE SALT LAKE BASIN (CENTRAL ANATOLIA, TURKEY)
}

Ali ALAŞ *, Murat KAYA ** and Ahmet ÖKTENER ***

\author{
* Necmettin Erbakan University, Faculty of A. K. Education, Department of Biology Education, \\ Meram-Konya, Turkey, TR-42090, alasali@hotmail.com \\ ** Aksaray University, Faculty of Science and Letters, Department of Biology, Aksaray, Turkey, \\ TR-68100,muratkaya3806@yahoo.com \\ *** Sheep Research Institute, Department of Fisheries, Çanakkale Street 7 km, Bandırma, Balıkesir, \\ Turkey, TR-10200, ahmetoktener@yahoo.com
}

KEYWORDS: Artemia salina, distribution, threats, Salt Lake.

\section{ABSTRACT}

In this study, the distribution and abundance of Artemia salina in 10 different stations of the Salt Lake basin were investigated. In addition, its relationship to $\mathrm{pH}$, dissolved oxygen, temperature, electrical conductivity and water levels were analyzed. Field studies were carried out from July to August of 2010. Artemia salina was observed in five of these stations. Artemia salina was not seen in some stations that have high electrical conductivity. It is determined that, in the station named Tersakan Lake where electrical conductivity was 154 $\mathrm{mS} / \mathrm{cm}$, Artemia salina is more abundant when compared to the other stations. But as underground water pumps that are built for the irrigation of agricultural lands decrease water levels, Artemia salina's life is under threat.

RESUMEN: Distribución y abundancia de Artemia salina en la Cuenca del Lago Salado (Central Anatolia, Turquia).

En este estudio, la distribución y la abundancia de Artemia salina en 10 diferentes estaciones de la cuenca del Lago Salado fueron investigadas. Además, su relación con el pH, oxigeno disuelto, temperatura, conductividad eléctrica y nivel del agua fueron analizados. Estudios de campo fueron llevados a cabo desde julio hasta agosto de 2010. La Artemia salina fue observada en cinco de las estaciones de estudio. La Artemia salina no fue vista en algunas de las estaciones que tienen alta conductividad eléctrica. Se determinó que, en la estación llamada Lago Tersakan, donde la conductividad electrica fue de $154 \mathrm{mS} / \mathrm{cm}$, la Artemia salina es mas abundante cuando comparada con otras estaciones. Pero como las bombas de agua subterráneas que se construyen para el riego de las tierras agrícolas disminuyen el nivel del agua, la vida de Artemia salina está bajo amenaza.

REZUMAT: Distribuția și abundența speciei Artemia salina în cuveta Lacului Sărat (Anatolia Centrală, Turcia).

În prezentul studiu, s-au analizat distribuția și abundența speciei Artemia salina în 10 puncte de prelevare diferite din lacul Tuz. De asemenea, au fost analizate efectele $\mathrm{pH}$-ului, ale oxigenului dizolvat, temperaturii, conductivității și nivelului apei asupra celor doi parametri populaționali considerați. Cercetările de teren au fost efectuate în perioada iulie-august 2010. Artemia salina a fost observată în cinci din cele 10 stații. Artemia salina a lipsit în unele stații, în care apa prezintă cantități mari de săruri dizolvate (conductivitate electrică mare). S-a concluzionat că în stația Tersakan Lake unde conductivitatea a fost de $154 \mathrm{mS} / \mathrm{cm}$, Artemia salina este mai abundentă decât în celelalte stații. Din păcate, forajele care pompează apă din pânză freatică pentru a fi folosită pentru irigarea terenurilor agricole scad nivelul apei, amenințând existența speciei. 


\section{INTRODUCTION}

Artemia salina appear naturaly in salt lakes, is used as live bait in aquariums, freshwater and marine fish culture, and as the main diet of some crustacean species because of its high nutritional value (Bengtson et al., 1991; Lengyel et al., 2012).

Artemia salina, which constitutes the second level of the food chain in the Salt Lake, feeds on suspended particles, bacteria and algae.

Similarly, flamingos and some other birds feed on Artemia salina.

This is why Artemia salina has a big importance on the energy cycle in the Salt Lake.

According to Başbuğ (1999), the Artemia salina species living in the Salt Lake, and it reproduces parthenogenetically.

In the same research on Artemia salina in 1995 (Başbuğ, 1999), reproduction aspects and fecundity were analyzed.

This study was carried out in order to determine and reveal the distribution of Artemia salina in the Salt Lake basin, its abundance and its relationship with water parameters in 10 different stations.

\section{MATERIAL AND METHODS}

Water was taken a total of eight times (200 liters) from each of the 10 stations (Tab. 1, Fig. 2) in the Salt Lake basin; the water was filtered with a $55 \mu \mathrm{m}$ plankton net and put into $500 \mathrm{ml}$ plastic bottles.

Right after this, $4 \%$ formaldehyde was added into the filtered samples and they were preserved.

The samples were brought to the laboratory and counted under a stereo microscope; individual numbers in the 200 liters were calculated and individual number per one $\mathrm{m}^{3}$ was determined.

On the other hand, some water parameters were calculated in this study.

Study area

Salt Lake (Fig. 1a, b) is situated at the center of Turkey (Fig. 2).

It is the second biggest lake in terms of square measure; it has borders with Aksaray, Konya and Ankara cities.

More than half of the country's salt need is supplied by this lake. Surface area of the lake is $1,500 \mathrm{~km}^{2}$ and the altitude is 905 meters. 


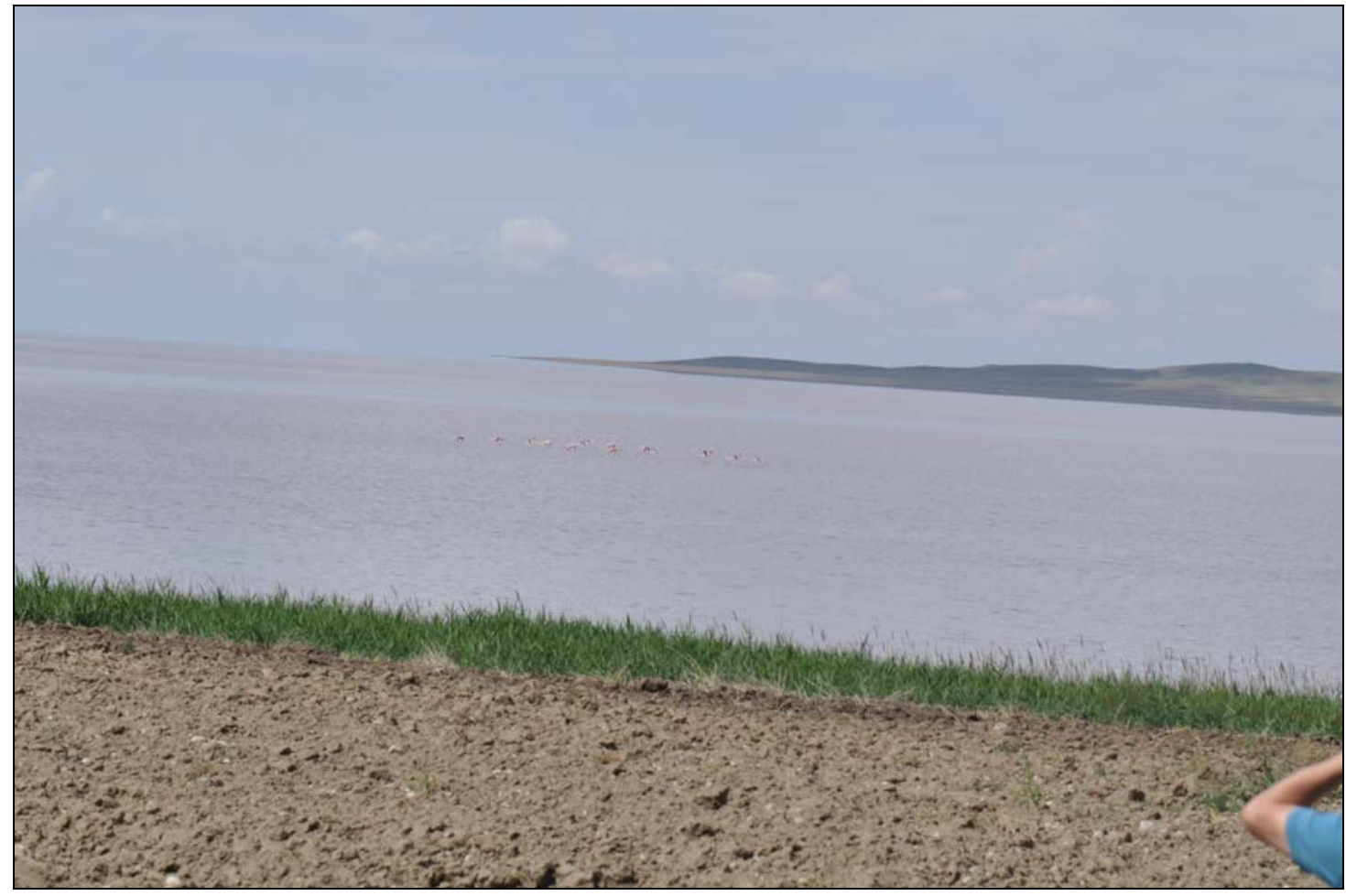

Figure 1a: Salt Lake.

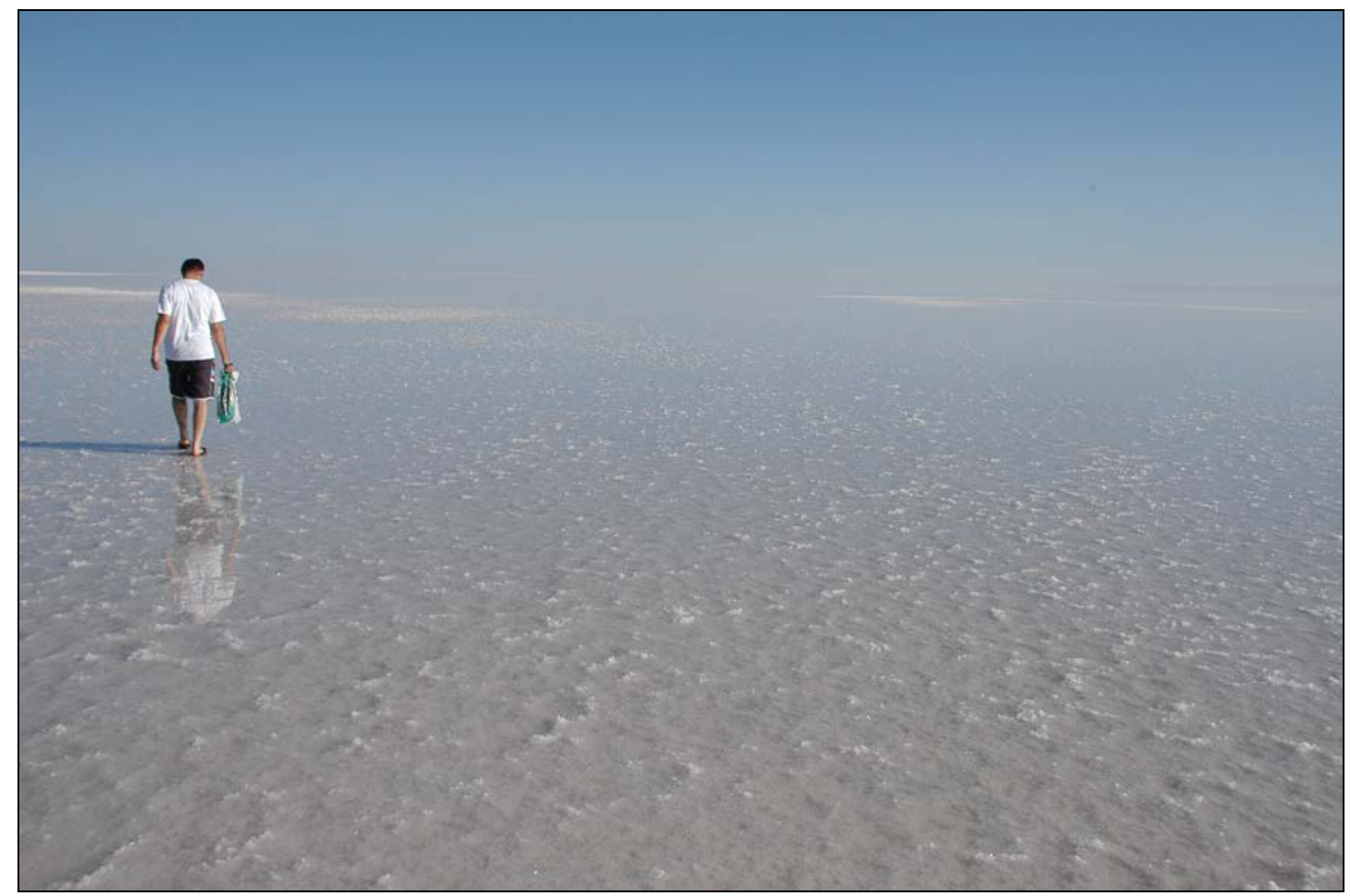

Figure 1b: Salt Lake. 


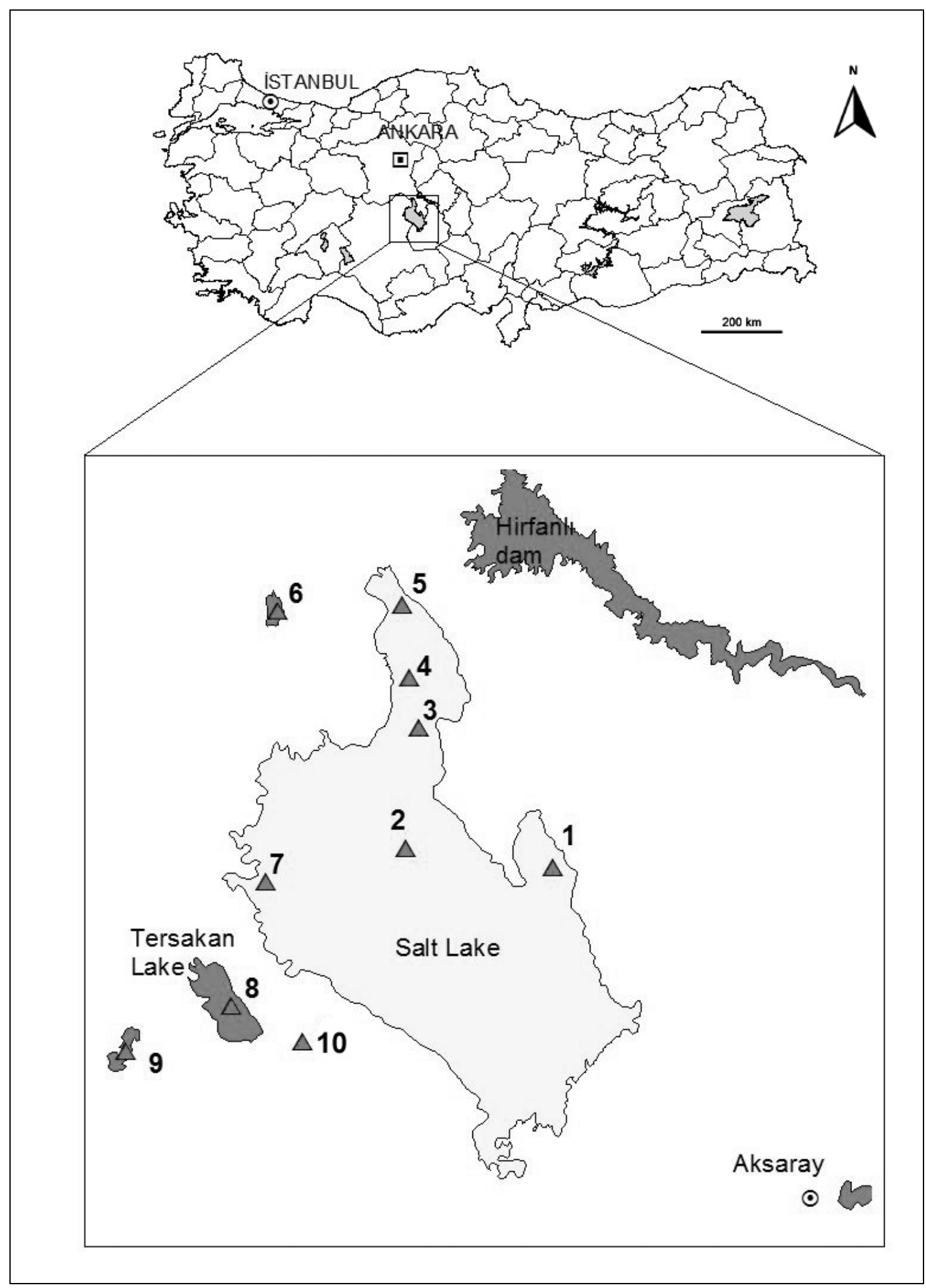

Figure 2: Sampling area and stations (1-10) in Salt Lake basin. 


\section{RESULTS AND DISCUSSION}

According to table 1, Artemia salina is observed only in five of these stations (1, 6, 8, 9, and 10). These water bodies are: Salt Lake Aksaray, Düden Lake, Tersakan Lake, Bolluk Lake and Ac1 Lake. All of the water bodies where Artemia salina was determined are separated from the main water resources of the Salt Lake and shaped as distinctive lakes in time. Artemia salina was not seen in other stations.

Table 1: Measured water parameters, coordinates and individuals in one $\mathrm{m}^{3}$ during the study in June, July and August of 2010.

\begin{tabular}{|c|c|c|c|c|c|c|c|c|c|c|c|c|c|c|c|c|c|c|c|}
\hline 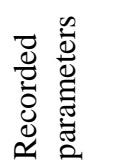 & & $\begin{array}{l}\mathrm{er} \mathrm{l} \\
\mathrm{cm}\end{array}$ & & & $\begin{array}{l}\text { vid } \\
\text { one }\end{array}$ & & & & & & $\begin{array}{c}\text { duc } \\
\end{array}$ & & & & & & $\mathrm{pH}$ & & \\
\hline 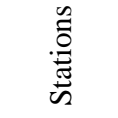 & 节 & $引$ & 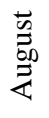 & 䇂 & $\frac{\otimes}{3}$ & 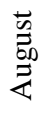 & 吾 & 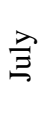 & $\begin{array}{l}\vec{y} \\
\vec{w} \\
\vec{z}\end{array}$ & 志 & $\exists$ & 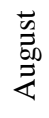 & 志 & 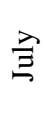 & $\begin{array}{l}\vec{y} \\
\vec{w} \\
\vec{z}\end{array}$ & 莺 & $\vec{\Xi}$ & $\begin{array}{l}\overrightarrow{9} \\
\text { wo } \\
\vec{z}\end{array}$ & \\
\hline 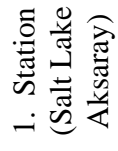 & $\stackrel{\mathscr{N}}{ }$ & $\stackrel{\llcorner}{N}$ & $\tilde{\sim}$ & 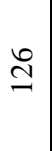 & $\stackrel{\infty}{\underset{\sim}{\sim}}$ & $\underset{\exists}{ت}$ & $\vec{N}$ & N & $\bar{N}$ & 号 & 㞻 & $\stackrel{\text { }}{\Omega}$ & $\stackrel{\bullet}{+}$ & $\stackrel{\infty}{+}$ & $\stackrel{\bullet}{\dot{\sim}}$ & $\stackrel{\sigma}{\Lambda}$ & $\stackrel{\infty}{\wedge}$ & $\stackrel{\infty}{\wedge}$ & \\
\hline 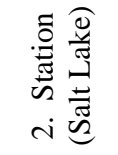 & 으 & $\sigma$ & $\stackrel{ }{\circ}$ & 0 & 0 & 0 & $\vec{N}$ & N & $\bar{N}$ & $\underset{\mathcal{F}}{\mathscr{F}}$ & F & ஜ্ণি & $\stackrel{\overbrace{}}{i}$ & $\vec{m}$ & $\stackrel{\circ}{\ddot{r}}$ & $\stackrel{\sigma}{\Omega}$ & $\stackrel{?}{\Lambda}$ & $\begin{array}{l}0 \\
\infty\end{array}$ & \\
\hline 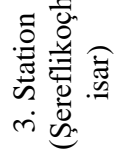 & $\sigma$ & $\sigma$ & $\sigma$ & 0 & 0 & 0 & $\vec{N}$ & $\bar{v}$ & $\bar{N}$ & $\stackrel{m}{n}$ & है & $\begin{array}{l}0 \\
\text { ํㅗ }\end{array}$ & $\stackrel{\infty}{i}$ & $\stackrel{\overbrace{}}{\sim}$ & 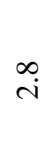 & 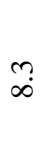 & $\sigma_{\infty}^{-1}$ & $\vec{\infty}$ & \\
\hline 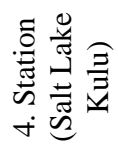 & $\sigma$ & $\infty$ & $\infty$ & 0 & 0 & 0 & $\vec{N}$ & הี & N & 号 & $\stackrel{m}{n}$ & $\ddot{\text { nี }}$ & $\stackrel{0}{\dot{m}}$ & $\stackrel{\nabla}{\oplus}$ & $\hat{\ddot{m}}$ & $\vec{\infty}^{-1}$ & $\stackrel{\infty}{\infty}_{\infty}$ & $\stackrel{?}{\top}$ & \\
\hline 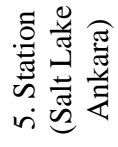 & $\infty$ & $\infty$ & $\infty$ & 0 & 0 & 0 & $\vec{N}$ & N & $\bar{\lambda}$ & 苛 & రิ & 范 & $\stackrel{\infty}{i}$ & $\stackrel{\circ}{\dot{m}}$ & $\vec{i}$ & $\stackrel{\circ}{\infty}$ & $\stackrel{\infty}{\wedge}$ & $\stackrel{\circ}{\infty}$ & \\
\hline 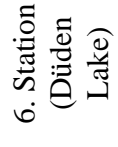 & $\ddot{N}$ & $\mathscr{N}$ & $\stackrel{\mathscr{N}}{ }$ & 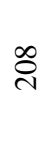 & $\tilde{N}$ & ָे & ন & ה & $\bar{N}$ & $\stackrel{m}{7}$ & $\underset{工}{ \pm}$ & 9 & $\stackrel{\llcorner}{\Lambda}$ & $\stackrel{\nabla}{\stackrel{ }{~}}$ & $\begin{array}{c}m \\
\infty\end{array}$ & $\sigma^{+}$ & $\ddot{\sigma}$ & m. & \\
\hline
\end{tabular}


Table 1 (continued): Measured water parameters, coordinates and individuals in one $\mathrm{m}^{3}$ during the study in June, July and August of 2010.

\begin{tabular}{|c|c|c|c|c|c|c|c|c|c|c|c|c|c|c|c|c|c|c|c|}
\hline 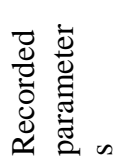 & \multicolumn{3}{|c|}{$\begin{array}{l}\text { Water level } \\
\quad(\mathrm{cm})\end{array}$} & \multicolumn{3}{|c|}{$\begin{array}{l}\text { Individuals } \\
\text { in one } \mathrm{m}^{3}\end{array}$} & \multicolumn{3}{|c|}{$\begin{array}{c}\text { Water } \\
\text { temperature } \\
\left({ }^{\circ} \mathrm{C}\right)\end{array}$} & \multicolumn{3}{|c|}{$\begin{array}{c}\text { Electrical } \\
\text { conductivit } \\
\mathrm{y} \\
(\mathrm{mS} / \mathrm{cm})\end{array}$} & \multicolumn{3}{|c|}{$\begin{array}{c}\text { Dissolved } \\
\text { oxygen } \\
(\mathrm{mg} / \mathrm{l})\end{array}$} & \multicolumn{3}{|c|}{$\mathrm{pH}$} & ڤn \\
\hline 韋 & $\stackrel{\Xi}{\Xi}$ & $\frac{2}{\Xi}$ & 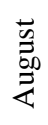 & 䍖 & $\vec{\Xi}$ & $\begin{array}{l}\vec{\omega} \\
\overrightarrow{0} \\
\vec{z}\end{array}$ & $\stackrel{\Xi}{\Xi}$ & $\overrightarrow{3}$ & 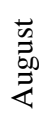 & $\stackrel{\Xi}{\Xi}$ & $B$ & & $\stackrel{\Xi}{\Xi}$ & $\stackrel{3}{3}$ & $\begin{array}{l}\vec{n} \\
\stackrel{0}{0} \\
\sum_{4}^{4}\end{array}$ & $\stackrel{\Xi}{\Xi}$ & $\vec{\Xi}$ & 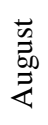 & \\
\hline 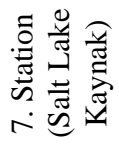 & 그 & $\underset{7}{ }$ & 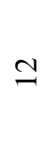 & 0 & 0 & 0 & $\stackrel{\curvearrowright}{ }$ & $\approx$ & $\vec{\nu}$ & Ð & శీ & & $\stackrel{\llcorner}{\forall}$ & เ & $\stackrel{\leftrightarrow}{\forall}$ & $\stackrel{\infty}{\circ}$ & $\stackrel{\infty}{\Lambda}$ & $\stackrel{\sigma}{\Lambda}$ & $\begin{array}{l}\hat{b} \\
0 \\
\infty \\
m \\
Z\end{array}$ \\
\hline 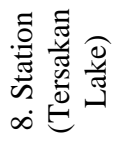 & б' & 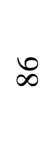 & $\mathbb{N}$ & $\begin{array}{l}\vec{G} \\
-\end{array}$ & ָิ & $\stackrel{\tilde{n}}{=}$ & $\stackrel{9}{-1}$ & $\vec{\sim}$ & $\vec{v}$ & $\stackrel{\infty}{\sim}$ & பு & & क. & $\stackrel{\omega}{\infty}_{\infty}^{0}$ & $\stackrel{\infty}{\infty}$ & $\stackrel{\sigma}{r}$ & $\stackrel{\infty}{\wedge}$ & חִ & 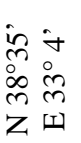 \\
\hline 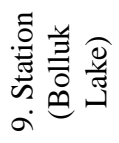 & $\mathscr{f}$ & ষ & 1 & $\stackrel{\substack{\infty \\
\sim}}{ }$ & సे & I & $\stackrel{\curvearrowright}{ }$ & $\curvearrowright$ & ' & $\vec{J}$ & 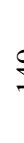 & & $\stackrel{\text { ?ִ }}{\Lambda}$ & $\stackrel{\nabla}{N}$ & 1 & $\stackrel{+}{\infty}$ & $\underset{\infty}{\sim}$ & 1 & $\begin{array}{l}0 \\
\text { m } \\
\infty \\
\infty \\
\text { m } \\
z\end{array}$ \\
\hline 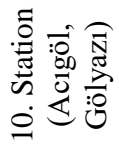 & 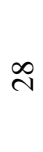 & N & ฟ & б & $\stackrel{\text { f }}{\sim}$ & దூ & $\stackrel{\sim}{ }$ & $\approx$ & $\bar{v}$ & $\stackrel{\nu}{v}$ & ใ & & $\stackrel{\nabla}{\forall}$ & $\stackrel{5}{\nabla}$ & $\stackrel{\nabla}{+}$ & $\widehat{\infty}$ & $\underset{\infty}{\infty}$ & $\begin{array}{l}\infty \\
\infty\end{array}$ & $\begin{array}{l}\bar{m} \\
\infty \\
\infty \\
m \\
z\end{array}$ \\
\hline
\end{tabular}

Distribution of Artemia salina in the Salt Lake

Artemia salina is able to live until 4,500 m altitude, which is a wide range (Xin et al., 1994). The Salt Lake study environment is situated at $905 \mathrm{~m}$ altitude. Artemia salina, living in hyper saline waters is recorded at more than 600 coastal and inland waters (Van Stappen, 2002). One of these water areas where Artemia salina is found naturally as stocks, is in Van Lake, the second biggest lake of Turkey in terms of square meters; it is situated at the center of the country (between Aksaray, Ankara and Konya cities). It is reported that Artemia salina in Turkey is found in Ayvalık Saltpan (Koru, 2006), Çamaltı Saltpan (Koru, 2004), Salt Lake Basin (Aksaray, Ankara and Konya) (Triantaphyllidis et al., 1998) and Gökçeada (Çanakkale). In the present study, Artemia salina is only found in five of the stations. These stations are; Salt Lake Aksaray, Düden Lake, Tersakan Lake, Bolluk Lake and Acı Lake.

Distribution of Artema salina in the Salt Lake is analyzed by Başbuğ (1999); according to the analysis of these samples collected from these stations, Artemia salina is found only in two stations (Devekonağ 1 and Çalören). During the past 15 years, water levels of some water sources decreased while some lakes completely disappeared. The station named as the 5th station by Başbuğ (1999) is the same area which we named as the 1st, Salt Lake Aksaray station in our study. Artemia salina's presence is determined in both studies in the area. Different from Başbuğ (1999), as in our study, new living spaces are determined where Artemia salina is distributed. 


\section{Abundance of Artemia salina in the Salt Lake}

According to the data of the field study, it was determined that the number of flamingos in the 8th station, named as Tersakan Lake, where Artemia salina is found densely, is much higher than the other water bodies. Related with Artemia salina density, it is observed that the flamingo numbers in Düden and Bolluk Lakes are higher than the number of flamingos in the area which we name as the 1st station (Salt Lake Aksaray) and in Acıgöl (Gölyazi). There were no flamingos in the other five areas where Artemia salina is not found. This result shows us that there is a direct proportion between the Artemia salina density and flamingo numbers.

It is observed that the electrical conductivity in the 8th station, Tersakan Lake, is the most suitable value for Artemia salina; and individual number measured per cubic meter is found to be very high in this station. Artemia salina is a very economic creature in terms of high feeding value, egg production and being used as aquarium fisheries in order to produce live bait. According to the study's result, in case of building a natural Artemia salina facility in future, the most suitable place is Tersakan Lake.

\section{Relation between electrical conductivity and Artemia salina}

At the end of measuring water parameters, we determined that in these five different areas in the Salt Lake, where Artemia salina is observed, the level of salinity content rate is much higher than the other aquatic areas. This result shows that Artemia salina can not accommodate in aquatic areas where salinity content rate is high. During the study, the lowest electrical conductivities were measured in July and August, at the 6th station as $13 \mathrm{mS} / \mathrm{sm}$ (Düden Lake); the highest electrical conductivity was measured in June, at the 3rd station as $517 \mathrm{~m}^{2} / \mathrm{cm}$ (Şereflikoçhisar) The densest electrical conductivity was in July, at the 8th station (Tersakan Lake) and measured to be $154 \mathrm{~m}^{2} / \mathrm{cm}$. On the other hand, Artemia salina is not seen in the stations where electrical conductivity is $204 \mathrm{~m}^{2} / \mathrm{cm}$ and $517 \mathrm{~m} / \mathrm{cm}$. In this case, 154 $\mathrm{m}^{2} / \mathrm{cm}$ values for electrical conductivity is defined to be the most appropriate value for Artemia salina's fertility. In addition to this, according to the measured values, $A$. salina can not live in $204 \mathrm{mS} / \mathrm{cm}$ or higher electrical conductivity.

\section{Relation between water levels and Artemia salina}

During the study, it was noticed that there are many underground water pumps in the region built for the irrigation of agricultural lands. These water pumps are used in the irrigation of agricultural lands during the summer season before waters reach the lake in the region. It is observed that water levels in the basin are very low because of the low water capacity of other water resources in the region during summer. Salinity levels increase as water heats up more during summer because of the low water levels. The increase in salinity levels create a toxic effect on Artemia salina. This is why, the lives of flamingos living in Salt Lake basin, whose essential nutrients is Artemia salina, are under threat.

Finally, the implications of these results might be valuable to balance the conservation and exploitation of natural populations of Artemia salina in the Salt Lake basin in Turkey. 


\section{REFERENCES}

1. Başbuğ Y., 1999 - Reproduction characteristics of Artemia salina (L., 1758) in Salt Lake, Turkish Journal of Zoology, 23, 2, 635-640.

2. Bengtson D., Leger P. and Sorgeloos P., 1991 - Use of Artemia as food source, in Browne R., Sorgeloos A. P. and Trotman C. N. A. (eds), Artemia Biology, CRC Pres. Boca Raton, Florida, USA, 255-285.

3. Koru E., 2004 - Çamaltı saltlası (İzmir, Türkiye) ekosisteminde Artemia ve önemi, E.U. Journal of Fisheries and Aquatic Sciences, 21, 187-189.

4. Koru E., 2006 - Ayvalık Saltlası'ndaki (Balıkesir/Türkiye) Artemia parthenogenetica'nın Yağ Asitleri Üzerine Bir Araştırma, E.U. Journal of Fisheries and Aquatic Sciences, 23, 185-187. (in Turkish)

5. Lengyel E., Oprean L., Tiţa O., Iancu R. and Iancu M., 2012 - Biodiversity of the microorgamisms existing in the salt lakes at Ocna Sibiului (Romania) and Chott El Jerid (Tunisia), Transylvanian Review of Systematical and Ecological Research, 14, The Wetlands Diversity, 25-32.

6. Triantaphyllidis G. V., Abatzopoulos T. J. and Sorgeloos P., 1998 - Review of the biogeography of the genus Artemia (Crustacea, Anostraca), Journal of Biogeography, 25, 213-226.

7. Van Stappen G., 2002 - Zoogeography, in Artemia: Basic and Applied Biology, Abatzopoulos et al. eds.), Kluwer, The Netherlands, 171-224.

8. Xin N., Sun J., Zhang B., Van Stappen G. V., Triantaphyllidis G. V. and Sorgeloos P., 1994 International study on Artemia, New survey of Artemia resources in the People's Republic of China, International Journal of Salt Lake Research, 3, 105-112. 